\title{
UN SIGILIU DE PLUMB AL LEGIUNII A XI-A CLAUDIA
}

\section{EUGEN PARASCHIV-GRIGORE}

\section{A LEAD SEAL OF LEGIO XI CLAUDIA}

The author presents, in this paper, a lead seal of Legio XI Claudia discovered in Dobroudja, kept on the National Museum of Romanian History's collections. This is one of the four seals of the Legio XI Claudia discovered so far in Dobroudja. The seal was most likely issued at the end of the $2^{\text {nd }}$ century or the beginning of the $3^{\text {rd }}$ century AD.

KEYWORDS: seal, Legio XI Claudia, Dobroudja.

CUVINTE CHEIE: sigiliu, Legiunea a XI-a Claudia, Dobrogea.

Primele sigilii de plumb descoperite pe teritoriul dobrogean datează de la începutul secolului al II-lea d. Hr. și sunt sigilii emise de către legiunile romane staționate pe limes-ul dunărean ${ }^{1}$. Sigiliul de plumb începe să fie folosit pentru sigilarea corespondenței și a produselor începând cu prima jumătate a secolului al II-lea şi să se extindă pe scară largă după sfârşitul secolului al III-lea, pentru ca în perioada romano-bizantină și bizantină să fie folosit tot mai des.

În anul 2002, în colecțiile Muzeului Național de Istorie a României, a intrat un sigiliu de plumb al Legiunii a XI-a Claudia. Conform registrului de inventar, această piesă este o donație a domnului Cosmin Galeriu. Locul și data de descoperire a piesei nu ne sunt precizate, dar cel mai probabil această piesă este o descoperire întâmplătoare de pe teritoriul dobrogean. Piesa a fost găsită cel mai probabil în zona de sud-vest a Dobrogei, pe raza județului Constanța, în zona Ostrov-Silistra. Această ipoteză este întărită de celelalte descoperiri de piese similare cunoscute din literatura de specialitate $^{2}$. Din zona Durostorum provin și alte piese sigilare datate pentru perioada secolelor al IIlea și al III-lea. Amintim de cele trei capsule sigilare descoperite fortuit în zona vechiului oraș roman și aflate în colecțiile Muzeului Dunării de Jos din Călărași $i^{3}$. Toate aceste descoperiri din această zonă vin să confirme faptul că orașul roman Durostorum, precum și suburbiile lui sunt un punct important în linia de apărare a frontierei romane. De remarcat că în această zonă au fost descoperite foarte multe sigilii de plumb (ce-i drept datate într-o perioadă mai târzie) atât comerciale, cât și particulare (folosite la sigilarea corespondenței $)^{4}$ și prin urmare afirmația cu privire la locul de proveniență al acestei piese nu este hazardată.

Descoperirile însemnate de material tegular, și nu numai, cu ștampila legiunii a XI-a Claudia din zona mai sus menționată ${ }^{5}$ constituie argumente să afirmăm că în această zonă şi-a avut sediul această legiune încă din secolul al II-lea ${ }^{6}$. Numărul de piese sigilare emise de către legiunea a XI-a Claudia și descoperite până în prezent nu este foarte mare. Acest lucru nu se datorează lipsei cercetării arheologice ${ }^{7}$, mai degrabă caracterului acestor piese. Fiind piese mici și dintr-un material ce poate fi reutilizat prin retopire, cel mai probabil aceste piese au fost refolosite de-a lungul anilor, ceea ce a

\footnotetext{
${ }^{1}$ Culică 1971, 193-199.

${ }^{2}$ Culică 1971, 193.

${ }^{3}$ Mușeteanu 1984, 362-365.

${ }^{4}$ Culică 1975, 215-262; Culică 1976, 116-133; Culică 1978, 120; Culică 1979, 145-149; Barnea 1982, 201-212; Barnea 1996, 215-220; Chiriac, Munteanu 2014, 299-330; Chiriac, Munteanu 2015, 147-156; Paraschiv-Grigore 2009, 303-30; Paraschiv-Grigore 2010, 127-132.

${ }^{5}$ Culică 1970, 376; Popa-Lisseanu 1913, 48.

${ }^{6}$ În secolul I d. Hr. Legiunea XI Claudia a fost cantonată la început în Dalmatia și apoi în Germania, după care a fost mutată la Durostorum, la începutul războaielor daco-romane - Keppie 2000, 37.

${ }^{7}$ În ultimii 20 de ani în perimetrul sud-vestic al județului Constanța au avut loc cercetări arheologice semnificative raportat la cercetarea arheologică întreprinsă în zonă înainte de anul 1989.
} 
făcut ca păstrarea lor până în zilele noastre să fie atât de restrânsă. Numărul de sigilii de plumb emise de către legiunile romane și păstrate până la momentul de față este foarte redus ${ }^{8}$.

Sigiliu păstrat în colecțiile Muzeului Național de Istorie a României are numărul de inventar 301637. Pe avers prezintă o imagine și o legendă, redate prin presare, cu litere în relief. Imaginea este a unui vultur cu aripile și ghearele desfăcute. Acestea sunt redate stilizat, prin linii. Capul vulturului nu se distinge din cauza deteriorării piesei. O legendă aflată de o parte și de alta a vulturului ne dezvăluie numele legiunii romane ce a emis sigiliul. Legenda este alcătuită din literele $L E G X I$. Deși sigiliul este rupt în dreptul literei $\mathrm{L}$, cel mai probabil înaintea acestei litere nu se afla o altă literă $(\mathrm{K})$ ca la alte sigilii emise de această legiune 9 . Litera G este parțial imprimată, acest lucru se datorează unei ștanțări incomplete. Înălțimea literelor este de cca $3 \mathrm{~mm}$, fiind mai mică faţă de înălțimea literelor de pe alte sigilii ale acestei legiuni ${ }^{10}$.

Literele inscripționate pe fața plumbului se citesc astfel:

L E G (ionis) X I (Claudiae)

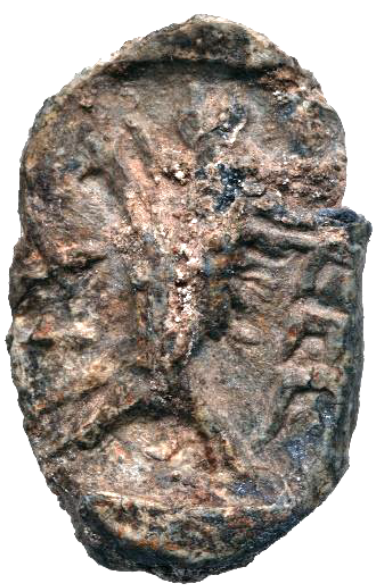

AVERS

Piesa este de formă ovală cu diametrul maxim de $21,07 \mathrm{~mm}$, iar cel minim de $13,34 \mathrm{~mm}$. Grosimea este de $4,28 \mathrm{~mm}$, iar greutatea de 5,52 g. Pe revers se observă canalul prin care era trecut şnurul pentru prindere. Starea de conservare a sigiliului este relativ bună, prezintă pe ambele fețe depuneri calcaroase care însă nu au deteriorat piesa.

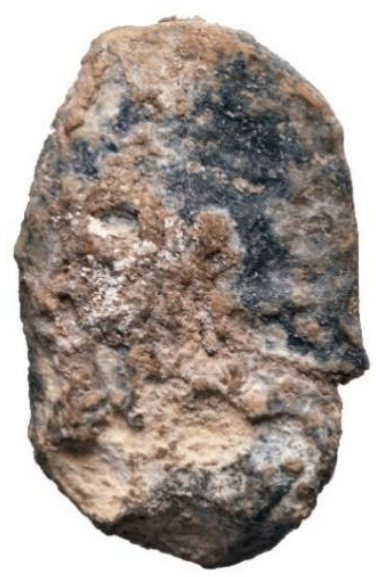

REVERS

\footnotetext{
8 Rostovtsev, Prou 1900, 22-23; Culică 1971, 193-198.

9 Lipsa literei K indică faptul că acest sigiliu a fost emis de către unitatea principală a legiunii și nu de către o cohortă sau detaşament auxiliar, vezi și Culică 1971, 178-179, fig. 1 și fig. 2.

${ }^{10}$ Culică 1971, 194.
} 
Legenda și imaginea imprimată pe avers se află încadrate într-un chenar dreptunghic care a căzut în mare parte în afara pastilei sigilare. Latura lungă a câmpului sigilar are $16,32 \mathrm{~mm}$, iar cea mică are aproximativ $12,17 \mathrm{~mm}$.

Față de cele trei piese publicate anterior ${ }^{11}$ şi descoperite pe malul Dunării în anii '60 ai secolului al XX-lea, piesa de față este total diferită. Cele trei piese publicate în anii ' 70 au formă de monedă și prezintă o legendă metrică pe două rânduri cu numele legiunii a XI-a Claudia. Se poate afirma că această piesă este emisă de către unitatea centrală a legiunii și nu de către detașamentele acesteia ce se aflau staționate în alte așezării ale provinciei. Existența în cadrul legendei numai a denumirii acesteia (nu și a literei $\mathrm{K}$ de la kastrum) indică faptul că acesta a fost emis de către detaşamentul principal al legiunii. Imaginea vulturului gravată pe sigiliu, este un element în plus care vine să confirme ipoteza noastră. Este cunoscut faptul că detașamentele legiunilor (cohortele) își confecționau sigiliile cu numele acestora şi difereau de cele ale detaşamentului principal ${ }^{12}$.

Un sigilu asemănător, emis de către Legio II Augusta ${ }^{13}$, este publicat și de către Michel Rostovtsev şi Maurice Prou în anul $1900^{14}$. Pe sigiliul descris de aceștia, vulturul apare ținând în cioc o coroană. Trebuie să spunem că deși vulturul (acvila) nu era emblema acestei legiuni, nu este un caz singular când pe sigilii este folosită imaginea vulturului. Același lucru este valabil și pentru Legio XI Caludia a cărei emblemă la început era Neptun (în epoca republicană când aceasta este înființată $\breve{a}^{15}$ ). Dar folosirea unei acvile (vultur) ca simbol pe sigilii nu este un lucru întâmplător. Acvila era un simbol al legiunilor romane și era folosit pe post de vârf de signum. Astfel de piese au fost descoperite la Barboși (jud. Galați) și sunt confecționate din bronz ${ }^{16}$. Acvila este redată cu aripile desfăcute și este foarte asemănătoare cu reprezentarea de pe sigiliul de față.

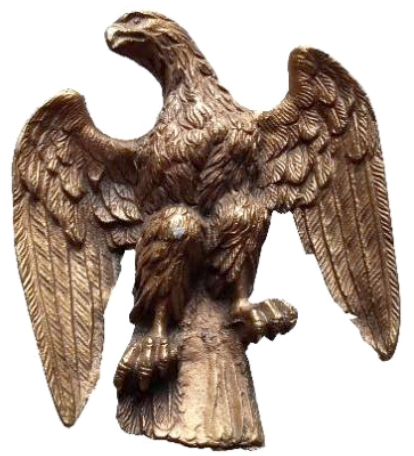

VÂRF DE SIGNUM DESCOPERIT LA BARBOȘI, JUD. GALAȚI (MNIR 101716)

Sigiliul de față a fost folosit cel mai probabil la recunoașterea expeditorului unui document și mai puțin la sigilarea unor produse comercializate de către această legiune.

Acest sigiliu nu poate fi datat anterior începutului secolului al II-lea d. H. deoarece legiunea a XI-a Claudia nu a activat în provincia Moesia Inferior mai devreme de războaiele daco-romane. Cea mai mare parte a cercetătorilor este de părere că legiunea a XI-a Claudia își stabilește baza în zona Durostorum în epoca lui Traian, după ce Traian cucerește Dacia și o transformă în provincie romană. Scopul instalării acestei legiuni în zona dobrogeană era acela de a apăra limes-ul roman, dar și de a interveni în caz de evenimente în provincia nou înglobată în imperiu. Prin urmare sigiliu se poate data pentru perioada cuprinsă între al doilea sfert al secolului al II-lea și sfârșitul secolului al III-lea. O datare precisă a acestuia este imposibil de realizat din cauza condițiilor de descoperire (piesa este descoperită întâmplător) și a unicității piesei. Coroborat cu celelalte piese sigilare emise de această legiune și care sunt datate pentru perioada cuprinsă între începutul secolului al II-lea și sfârșitul secolului al III-lea, cel mai sigur și această

\footnotetext{
${ }^{11}$ Culică 1971, fig. 1 și 2.

${ }^{12}$ Rostovtsev, Prou 1900, 22-23.

${ }^{13}$ Keppie 2000, 128-129. Inițial aceasta a purtat numele de Legio II Sabina, însă în epoca lui Augustus, legiunea a fost reorganizată şi redenumită.

${ }^{14}$ Rostovtsev, Prou 1900, 22-23

${ }^{15}$ Keppie 2000, 35-40.

${ }^{16}$ O piesă se află în colecțiile Muzeului Național de Istorie a României (nr. inv. 101716), iar o a doua piesă se află în colecțiile Muzeului de Istorie „Paul Păltănea”, Galaţi.
} 
piesă se încadrează în această perioadă de timp. Trebuie menționat faptul că astfel de piese sunt utilizate până la sfârșitul secolului al III-lea (toate sigiliile emise de legiunile romane se opresc la sfârșitul secolului al III-lea). Cel mai probabil o dată cu reformele lui Diocletian rolul legiunilor romane în economia imperială scade, acesta fiind redus doar la rolul militar și mai puțin la cel economic. Legiunile devin prin urmare doar unităţi militare însărcinate exclusiv cu apărarea teritoriului imperiului. Prin urmare, acestea sunt întreținute din visteria statului și nu mai sunt folosite la activități economice. . Dispariția legiunilor romane duce și la dispariția sigiliilor emise de acestea, ce vor fi înlocuite de către sigiliile private emise de către comandanții militari în nume personal sau al unităților militare nou înființate.

Deși sigiliilie emise de către legiunile romane ajunse până la noi sunt în număr foarte mic (raportat la alte tipuri de sigilii), importanța acestora este cu atât mai mare. Folosite la sigilarea corespondenței sau la autentificarea produselor comercializate de acestea, sigiliile descoperite până în prezent oferă informații cu privire la arealul în care acestea își aveau zona de influență precum și cu privire la mișcările acestora pe teritoriul imperiului în perioada cuprinsă între începutul secolului al IIlea și sfârşitul secolului al III-lea.

BIBLIOGRAFIE

Barnea 1982

Barnea 1996

Chiriac, Munteanu 2014

Chiriac, Munteanu 2015

Culică 1970

Culică 1971

Culică 1975

Culică 1976

Culică 1978

Culică 1979

Keppie 2000

Paraschiv-Grigore 2009

Paraschiv-Grigore 2010

Rostovtsev, Prou 1900

Mușeteanu 1984

Popa-Lisseanu 1913
I. Barnea, Sigilii bizantine de la Durostorum - Dorostolon, Pontica, XV, 1982, p. 201-212

I. Barnea, Sigilii bizantine din Dobrogea, SCIVA, 47, 2, 1996, p. 215-220

C. Chiriac, L. Munteanu, Trade connections between Asia Minor and the Western Pontic Area in the $4^{\text {th }}$ Century CE. Some sphragistic considerations, în V. Cojocaru, A. Coșkun, M. Dana (ed.), Interconnectivity in the Mediterranean and Pontic World during the Hellenistic and Roman Periods, Cluj-Napoca, 2014, p. 299-330

C. Chiriac, L. Munteanu, Sigilii dobrogene inedite. III, ArhMold, 38, 2015, p. $147-156$

V. Culică, Cărămizi, țigle și olane cu ștampila legiunii a XI-a Claudia găsite în Canabae Aellie, Pontica, 3, 1970, p. 365-377

V. Culică, Plumburi ale legiunii a XI-a Claudia găsite în sud-vestul Dobrogei, Studii şi cercetări de numismatică , 5, 1971, p. 193-198

V. Culică, Plumburi comerciale din cetatea romano-bizantină de la Izvoarele, Pontica, VIII, 1975, p. 215-262

V. Culică, Plumburi comerciale din cetatea romano-bizantină de la Izvoarele (IV-V), Pontica, IX, 1976, p. 116-133

V. Culică, Cu privire la lagărul Legiunii a XI-a Claudia la Dunărea de Jos, Pontica, XI, 1978, p. 113-122

V. Culică, Plumburi comerciale din cetatea romano-bizantină de la Izvoarele (Addenda et corrigenda), Pontica, XII, 1979, p. 149-173

L.J.F. Keppie, Legions and Veterans: Roman Army Papers, 1971-2000, Stuttgart

E. Paraschiv-Grigore, Patru sigilii romano-bizantine și bizantine descoperite în Dobrogea, Cercetări Numismatice, 15, 2009, p. 303-307

E. Paraschiv-Grigore, Două noi sigilii de plumb descoperite în Dobrogea, CA, 17, 2010, p. 127-132

M.I. Rostovtsev, M. Prou, Supplément au catalogue des Plombs antiques de la Bibliothèque Nationale, Revue Numismatique, seria 4, tom 4, 1900, p. 1411

C. Muşeţeanu, Capsule de sigilii romane din Dacia şi Moesia Inferioară, SCIVA, 35, 1984, 4, p. 361-366

G. Popa-Lisseanu, Incercare de monografie asupra cetății Drâstorului Silistra, București, 1913 